\title{
The porcine virome and xenotransplantation
}

\author{
Joachim Denner
}

\begin{abstract}
The composition of the porcine virome includes viruses that infect pig cells, ancient virus-derived elements including endogenous retroviruses inserted in the pig chromosomes, and bacteriophages that infect a broad array of bacteria that inhabit pigs. Viruses infecting pigs, among them viruses also infecting human cells, as well as porcine endogenous retroviruses (PERVs) are of importance when evaluating the virus safety of xenotransplantation. Bacteriophages associated with bacteria mainly in the gut are not relevant in this context. Xenotransplantation using pig cells, tissues or organs is under development in order to alleviate the shortage of human transplants. Here for the first time published data describing the viromes in different pigs and their relevance for the virus safety of xenotransplantation is analysed. In conclusion, the analysis of the porcine virome has resulted in numerous new viruses being described, although their impact on xenotransplantation is unclear. Most importantly, viruses with known or suspected zoonotic potential were often not detected by next generation sequencing, but were revealed by more sensitive methods.
\end{abstract}

Keywords: Porcine viruses, Virome, Xenotransplantation, Porcine endogenous retroviruses, Porcine cytomegalovirus, Porcine circoviruses, Hepatitis E virus

\section{Background}

Xenotransplantation is being developed to overcome the shortage of human tissues and organs needed to treat organ failure by allotransplantation. Pigs are the preferred species to be used as donor animals for a number of reasons including the size of the animals, their similar physiology, and the ease with which they can be genetically modified and cloned.

Although there are still some hurdles that have to be overcome, such as immunological rejection, physiological incompatibility and risk of transmission of porcine microorganisms, recent achievements in breeding genetically modified pigs, in the development of new immunosuppressive regimens and in approaches to safety suggest that xenotransplantation may soon be introduced in the clinic (for review see [1-3]).

In the past, only a few porcine viruses with known or suspected ability to infect human cells or to accelerate transplant rejection have been analysed within the context of xenotransplantation. Next generation sequencing or deep sequencing techniques and metagenomic analyses now give the opportunity to analyse the entire

Correspondence: DennerJ@rki.de

Robert Koch Fellow, Robert Koch Institute, Nordufer, 20 Berlin, Germany virome of pigs and its impact on xenotransplantation. These studies on the pig virome are, like investigations into the virome of humans and other species, only at their very early stages [4]. The development of metagenomics has revolutionised virus discovery, leading to the identification of many new viruses. These studies will generate an enormous amount of data concerning the prevalence of porcine viruses although these will be difficult to interpret, especially with regard to the virus safety of xenotransplantation.

\section{Xenotransplantation and public health}

By March 3, 2017, 118,265 waiting list candidates were listed at UNOS (United network for organ sharing), among them 98,149 for kidney transplantations. However, in 2016 only 19,061 kidney transplantations were performed in the US, indicating the increasing gap between supply and demand, and the figures for heart transplantations were 3191 versus 3994 (https://www.unos.org/). Xenotransplantation could help to overcome this shortage. Another field where xenotransplantation may have an enormous impact on public health is the treatment of diabetes. In 2012, 29.1 million Americans, or $9.3 \%$ of the population, had diabetes, among them 
approximately 1.25 million children and adults with type 1 diabetes (http://www.diabetes.org/diabetes-basics/ statistics/). Although the treatment of diabetes type 1 with insulin was quite successful in the past using pig insulin and only recently recombinant human insulin, complications were often observed, mainly due to insufficient compliance of the patients leading to limb amputation and blindness. The total cost of diagnosed diabetes in the United States in 2012 was 245 billion dollars, most of which was spent on the treatment of complications while expenditure for insulin was relatively low. A biologically regulated system based on porcine islet cells would help avoid these complications [5]. Xenotransplantation therefore has the potential to have an enormous impact on public health.

\section{The porcine virome}

As described in the abstract, the pig virome is the total amount of viruses in and on the pig body and includes also the endogenous retroviruses. Initial attempts to analyse the porcine virome were undertaken using samples of the gut or faeces. These studies were started to better understand the reasons for neonatal porcine diarrhoea, a common problem worldwide that contributes to morbidity and mortality among piglets [6]. Although investigations of the porcine intestinal virome are so far limited [7-9], samples from the distal jejunum of 19 healthy pigs in a Swedish conventional herd yielded eight different viral families (Table 1). The most common were picornaviruses, followed by circoviruses [10]. Viral infections were already observed 24 to $48 \mathrm{~h}$ after birth, indicating infection immediately post-partum, or alternatively, transplacental infection. Similar results were obtained when Chinese pigs were analysed [7] where, in addition to the viruses identified in Sweden, the coronaviruses transmissible gastroenteritis virus (TGEV) and porcine epidemic diarrhoea virus (PEDV) were found (Tables 2 and 3). In this study, the virus

Table 1 Main virus families of the pig virome [10]

\begin{tabular}{llll}
\hline Virus family & Characterisation $^{\text {a }}$ & $\begin{array}{l}\text { Prevalence in } \\
\text { healthy pigs } \\
(\%, n=19)\end{array}$ & $\begin{array}{l}\text { Prevalence in Swedish } \\
\text { diarrhoeic pigs } \\
(\%, n=10)\end{array}$ \\
\hline Adenoviridae & dsDNA & 16 & 0 \\
Anelloviridae & ssDNA & 5 & 10 \\
Astroviridae & ssRNA & 5 & 0 \\
Caliciviridae & ssRNA & 5 & 0 \\
Circoviridae & ssDNA & 42 & 10 \\
Parvoviridae & ssDNA & 11 & 0 \\
Picornaviridae & ssRNA & 53 & 40 \\
Reoviridae & dsRNA & 11 & 20
\end{tabular}

${ }^{a s s}$ single stranded, $d s$ double stranded
Table 2 Main viruses in the faeces of healthy Chinese pigs [7]

\begin{tabular}{lll}
\hline Virus & $\%$ & Virus family \\
\hline Porcine bocavirus & 7 & Parvoviridae \\
Porcine epidemic diarrhea virus (PEDV) & 7 & Coronaviridae \\
Sapovirus & 17 & Caliciviridae \\
Sapelovirus & 17 & Picornaviridae \\
Torovirus & 7 & Coronaviridae \\
Posavirus-1 & 17 & Picornaviridae \\
Porcine astrovirus & 72 & Astroviridae \\
Porcine enterovirus-9 & 86 & Picornaviridae \\
Kobuvirus & 90 & Picornaviridae \\
\hline
\end{tabular}

prevalence rates revealed that all samples were coinfected with at least two different viruses and that, notably, co-infection with 11 different viruses was identified in one sample [7]. Detailed analyses of German sows showed that the pig faecal virome is highly variable and its general composition is mainly dependent on the age of the pigs [11]. Kobuviruses were predominantly detected in 12 day-old piglets, bocaviruses and others in 54 day-old piglets and circoviruses in the sows $[11,12]$.

Viral metagenomics analysis in healthy and pigs suffering from the postweaning multisystemic wasting syndrome (PMWS) showed that pigs have a considerable viral flora consisting mainly of small single-stranded and circular DNA viruses [13]. Although many viruses were also detected in the healthy pigs, the number of porcine circovirus 2 (PCV2) had increased considerably in the PMWS pigs.

Table 3 Main viruses in the faeces of diarrhoeic Chinese pigs [7]

\begin{tabular}{lll}
\hline Virus & $\%$ & Virus family \\
\hline Porcine bocavirus-2 & 59 & Parvoviridae \\
Porcine bocavirus-4 & 18 & Parvoviridae \\
Torque teno sus virus-2 (TTSUV-2) & 7 & Anelloviridae \\
Porcine epidemic diarrhea virus (PEDV) & 70 & Coronaviridae \\
Porcine stool associated circular virus (PoSCV) & 7 & $?$ \\
Po-circo-like & 11 & $?$ \\
Sapovirus & 33 & Caliciviridae \\
Sapelovirus & 48 & Picornaviridae \\
Torovirus & 33 & Coronaviridae \\
Posavirus-1 & 40 & Picornaviridae \\
Porcine astrovirus & 74 & Astroviridae \\
Coronavirus & 7 & Coronaviridae \\
Porcine enterovirus-9 & 85 & Picornaviridae \\
Picobirnavirus (PBV) & 15 & Picobirnaviridae \\
Kobuvirus & 44 & Picornaviridae \\
\hline
\end{tabular}


When pig mucus (the raw material for production of heparin) was investigated, parvoviruses $(76 \%$, within this group bocaviruses represent $80 \%$ ), circoviruses (16\%) and picornaviruses (2.5\%) were mainly found [14]. Viruses known to be transmissible to humans such as influenza virus, hepatitis E virus (HEV) and encephalomyocarditis virus (ECMV) $[15,16]$ were not found.

When the virome of feral swine (wild boars) in the US was analysed, a total of 16 different viruses were identified [17]. Mainly single stranded DNA viruses were detected including Circoviridae, Anelloviridae and Parvovirinae. Torque teno virus (Anelloviridae) was the most commonly detected virus (73\%), PCV2 was identified in $13 \%$ of the samples. Only four RNA viruses were identified: kobuvirus, sapelovirus, pestivirus and an orthopneumovirus [17]. This is in contrast to previous studies of the faecal virome which were dominated by RNA viruses [6, 7]. Feral swine in Texas were also commonly infected with influenza $A$ virus and the $\mathrm{H} 1 \mathrm{~N} 1$ 2009 virus [18], representing a reservoir for domestic pigs and zoonotic infection [18-20]. Meanwhile it was shown that influenza virus transmission from human to swine is far more frequent than swine-to-human zoonosis [21]. This implies that the staff working in facilities producing pigs for xenotransplantation should be screened for influenza virus.

It is important to underline, that cells and organs for xenotransplantation will be derived from pigs kept under specified pathogen free (SPF) or defined pathogen free (DPF) conditions. SPF means that the herds are free from a list of specified pathogens. SPF piglets are usually produced by Caesarean delivery and reared under sterile conditions. During this time they may be given a probiotic flora and sterilised colostrum supplement. They are then removed from the isolator and placed in a very clean room under hygienic conditions (http://www.thepigsite.com/pighealth/article/29/bypigs/). This means that the virome of the donor pigs will be well-defined. The knowledge of the virome of feral and farmed animals will be useful in understanding the prevalence of certain viruses and for the development of detection methods and elimination programs.

Since PERVs cannot be eliminated this way, they represent a special risk for xenotransplantation (see below).

For comparison it may be interesting to give a short summary about research on the human virome. The human virome was determined in the context of faecal transplantation against Clostridium difficile infection [22]. When analysing longitudinal variation in the human gut virome, loss and acquisition of viral types was found uncommon [23]. When the blood virome in 8000 humans was investigated, 94 different viruses were found, among them 19 DNA viruses [24]. These viruses were found in $42 \%$ of the individuals with a copy number of two to millions per 100,000 cells. Herpesviruses (altogether $41.6 \%$ ) and anelloviruses (8.91\%) were the most common viruses (Table 4). Among the viruses were numerous potentially pathogenic viruses such as Merkel cell polyomavirus (MCPV), human immunodeficiency virus (HIV), human T cell lymphotropic virus (HTLV), papillomaviruses and others.

It is interesting that samples from sick individuals have yielded viruses more frequently than samples from healthy controls $[25,26]$ and that infection with one virus may significantly change the composition of the virome. When the influence of a HIV-1 infection on the virome in humans was analysed, significant changes were observed when a clinically validated cutoff of less than $200 \mathrm{CD}^{+}$cells $/ \mathrm{ml}$ was used. Significantly more Adenoviridae and Anelloviridae sequences were detected in HIV-positive subjects with $\mathrm{CD}^{+}$lower than 200 cells/ml when compared with HIV-negative and HIVpositive subjects with $\mathrm{CD}^{+}$greater 200 [27], indicating that expansion of both viruses is associated with HIV induced immunosuppression.

\section{Risk posed by porcine viruses}

In addition to the possible transmission of porcine bacteria and fungi, which may be eliminated using

Table 4 Detected human viruses in blood DNA of 8240 humans [24]

\begin{tabular}{|c|c|c|}
\hline Virus & Abbreviation & $\begin{array}{l}\text { Percentage of } \\
\text { individuals }\end{array}$ \\
\hline Human herpesvirus 7 & $\mathrm{HHV}-7$ & 20.38 \\
\hline $\begin{array}{l}\text { Human herpesvirus } 4 \\
\text { (Epstein Barr virus) }\end{array}$ & $\begin{array}{l}\mathrm{HHV}-4 \\
\text { (EBV) }\end{array}$ & 14.45 \\
\hline Anellovirus & TTV \& TLMV ${ }^{a}$ & 8.91 \\
\hline Human herpesvirus $6 \mathrm{~A}$ & HHV-6A & 4.80 \\
\hline Human herpesvirus 6B & HHV-6B & 1.47 \\
\hline Merkel cell polyomavirus & MCPV & 0.59 \\
\hline $\begin{array}{l}\text { Human herpesvirus } 5 \\
\text { (Human cytomegalovirus) }\end{array}$ & $\begin{array}{l}\text { HHV-5 } \\
\text { (HCMV) }\end{array}$ & 0.35 \\
\hline Human T-lymphotropic virus $1 / 2$ & HTLV-1/2 & 0.27 \\
\hline Human papillomavirus & HPV & 0.19 \\
\hline $\begin{array}{l}\text { Human herpesvirus } 1 \\
\text { (Herpes simplex virus) }\end{array}$ & $\begin{array}{l}\mathrm{HHV}-1 \\
(\mathrm{HSV})\end{array}$ & 0.12 \\
\hline Human parvovirus B19 & & 0.12 \\
\hline Human adenovirus & & 0.11 \\
\hline Human immunodeficiency virus $1 / 2$ & HIV-1/2 & 0.06 \\
\hline $\begin{array}{l}\text { Human herpesvirus } 8 \\
\text { (Kaposi sarcoma herpesvirus) }\end{array}$ & $\begin{array}{l}\text { HHV-8 } \\
\text { (KSHV) }\end{array}$ & 0.04 \\
\hline Human polyomavirus & & 0.04 \\
\hline Hepatitis C virus & $\mathrm{HCV}$ & 0.01 \\
\hline
\end{tabular}

${ }^{\mathrm{a}} T V$ Torque teno virus, TLMV TTV-like minivirus 
antibiotics and antimycotics, transmission of viruses through xenotransplantation may lead to disease in the recipient, i.e. zoonoses [28]. For most porcine viruses there are neither antivirals nor vaccines available. However, it is still unclear whether porcine viruses can actually infect humans and cause zoonoses. In contrast to human pathogens that are well adapted to humans, porcine microorganisms are not. For only a few porcine viruses a zoonotic potential has been described, for example for HEV, genotype 3 . HEV induces a chronic infection in immunosuppressed patients and severe disease in patients with a pre-existing liver failure (for review see $[29,30])$. Of special interest is the porcine cytomegalovirus (PCMV) which may be indirectly pathogenic without infecting cells of the host. In preclinical trials of transplanting pig kidneys into cynomolgus monkeys and baboons, the presence of PCMV led to early transplant failure (for review see [31]). Since there is still no evidence for PCMV infection of non-human primate as well as human cells, the organ failure was possibly due to cytokines produced in response to viral antigens [31].

Porcine lymphotropic herpesvirus (PLHV) 1, 2, and 3 are common porcine herpesviruses, but their prevalence and importance for xenotransplantation is not well understood [32, 33]. PLHV may be transmitted by pre-partum cross-placental vertical transfer or post-partum horizontal transmission, although the former is relatively rare. Between $26 \%$ and $88 \%$ of animals in different herds in Germany, Ireland, France, Spain and the United States are infected with one of the PLHV variants [34-37] and, unlike PCMV, early weaning cannot eradicate PHLV [38].

Porcine circoviruses (PCV), the smallest viruses replicating autonomously in mammalian cells, are also widely distributed (for review see [39]). There are two types, porcine circovirus 1 (PCV1), which is apathogenic in pigs, and PCV2, which causes a severe multifactorial disease (PCV2 disease, PCVD, formerly postweaning multisystemic wasting syndrome, PMWS). Although the presence of PCV2 is necessary for the disease, additional factors are also required and the severity of the disease depends on the status of the immune system and genetic predisposition. There is no serological evidence indicating transmission of PCV2 to humans and indeed, the case of a human rotavirus vaccine being contaminated with PCV demonstrated that PCV was not transmitted to the vaccinated humans [40, 41]. Infection experiments with human cell lines showed persistence of PCV1 in most cell lines without causing any visible changes, but cytopathogenic effects in PCV2-transfected cells [42]. Most importantly, the infection appeared to be nonproductive $[42,43]$.
It is interesting to note that porcine viruses with a known or suspected zoonotic potential such as the herpesviruses PCMV and PLHV were not detected when viromes were analysed in faeces and blood [7-10] whereas PCV (mainly PCV2) was commonly found [7-10]. Presumably, the frequency of the herpesviruses is so low that their DNA cannot be detected by next generation sequencing. Indeed, only low numbers of herpesvirus sequences were found in German sows [11, 12] and in swine intestinal mucus, the raw material for the manufacture of heparin [14]. Similarly, next generation sequencing of human samples failed to identify low-level viruses that are revealed using viral particle enrichment or PCR amplification $[44,45]$. The most effective approach was serological profiling, detecting virus-specific antibodies in human sera using a synthetic human virome [46]. Testing 569 human donors across four continents with this method revealed antibodies to an average of 10 human viral species per person and 84 species in at least two individuals [46].

Whereas the zoonotic potential of many pig viruses is still unknown, some viruses are well characterised zoonotic viruses. One example is the hepatitis $\mathrm{E}$ virus (HEV) which can be easily transmitted by consumption of undercooked pork or by contact to pigs and which can induce disease and chronic infection in immunosuppressed individuals and in people with liver failure (for review see [30]). A second example is the paramyxovirus Nipah virus, which was transmitted from pigs to humans mainly working in slaughterhouses in Malaysia and Singapore $[47,48]$. The virus induced severe infections of the respiratory tract and encephalitis in humans, $48 \%$ of the infected died [47, 48]. The Menangle virus was first described in a piggery in Australia experiencing a high number of stillbirths and deformities during farrowing. Two workers at the piggery got infected and had a serious flu-like illness [49]. Nipah virus and Menagle virus had their origin in fruit bats [50]. Rabies is considered a rare disease in pigs, however an infection with the rabies virus is invariably fatal in all species including the human $[49,51]$. Another rhabdoviruses, the vesicular stomatitis virus (VSV) can infect insects, cattle, horses and pigs and is zoonotic, inducing flu-like illness in infected humans [52]. The Eastern equine encephalomyelitis virus (EEEV) and the Japanese encephalomyelitis virus (JEV) are two arboviruses infecting pigs. The transmission cycle of the JEV involves pigs as virus amplifiers and mosquitoes as vectors for transferring the virus between amplifying hosts and to dead-end hosts, i.e. humans, horses and cattle [53]. In pigs, it can cause abortion and stillbirths. In an outbreak of EEEV infection in swine, 280 of 350 pigs died. Histopathologic changes in the brain, multifocal necrosis and inflammation in the myocardium were seen. Growth retardation was noticed in surviving pigs [54]. Pigs can be protected 
from EEEV infection by a vaccine [55]. Domestic swine in the Philippines have been discovered to host Reston ebolavirus (REBOV) [56]. Although REBOV is the only member of Filoviridae that has not been associated with disease in humans, its emergence in the human food chain is of concern.

\section{Porcine endogenous retroviruses}

Whereas the viruses discussed above may be eliminated by selection, treatment, vaccination, Caesarean delivery, early weaning and embryo transfer, this is impossible in the case of porcine endogenous retroviruses (PERVs). These viruses are the result of infections with retroviruses in the distant past. Retroviruses possess enzymes able to transcribe the viral RNA genome into DNA copies and to integrate them into the cellular genome to form proviruses [57]. If oocytes or sperm cells happen to become infected, these proviruses will be present in all cells of the developing progeny and will be inherited in the same way as all other genes. Endogenous retroviruses have been found in all mammals including humans [57]. However, in contrast to the human endogenous retroviruses which are mostly defective and do not produce infectious particles, many retroviruses in other species remain active. Gamma- and betaretroviruses have been found integrated into the genome of pigs $[58,59]$ and sequencing of the entire pig genome (Sus scrofa) revealed 212 PERV insertions in the genome [60]. The gammaretroviruses include PERV-A and PERV-B, which are integrated into the genome of all pigs, and PERV-C, found in many (but not all) pigs. PERVs are produced as infectious virus particles and may infect human cells [61-63]. In addition, recombinants between PERV-A and PERV-C have been found that are highly replication-competent (for review see [64]). PERVs, like most other retroviruses, may theoretically induce tumours and/or immunodeficiency, but their zoonotic potential remains unknown and no PERV transmission was observed in pig-to-non-human primate preclinical trials and initial clinical trials [63, 65-67]. Recently all PERVs in the genome of an immortalised PK15 cell line (62 copies) and in primary fibroblasts (25 copies) were inactivated using CRISPR/Cas specific for the highly conserved pol gene of PERV [68, 69]. After a somatic cell nuclear transfer live and healthy pigs with inactivated PERVs could be generated [69]. This approach reduces the risk posed by PERVs to zero.

\section{Conclusion}

Next generation sequencing and metagenomic analyses allow the entire virome of pigs to be characterised and will result in the detection of many new porcine viruses. However, the impact of these viruses on xenotransplantation is unclear. Until now, porcine viruses with known or suspected zoonotic potential, although often detected by other methods, have been rarely detected by next generation sequencing and their detection appears to require other, more sensitive methods. Furthermore, it remains unclear whether there are other potentially zoonotic viruses not detected by next generation sequencing and not yet investigated using more sensitive methods.

\begin{abstract}
Abbreviations
ds: double stranded; EBV: Epstein Barr virus; ECMV: Encephalomyocarditis virus; H1N1 2009 virus: haemagglutinin 1 and neuraminidase 12009 influenza virus; HCMV: Human cytomegalovirus; HCV: Hepatitis C virus; HEV: Hepatitis E virus; HHV-1: human herpesvirus 1; HHV-4: Human herpesvirus 4; HHV-5: Human herpesvirus 5; HHV-6A: Human herpesvirus 6A; HHV-6B: Human herpesvirus 6B; HHV-7: Human herpesvirus 7; HHV-8: Human herpesvirus 8; HIV-1/2: Human immunodeficiency virus 1/2; HPV: Human papillomavirus; HSV: Herpes simplex virus; HTLV-1/2: Human T-lymphotropic virus 1/2; KSHV: Kaposi sarcoma herpesvirus; MCPV: Merkel cell polyomavirus; PBV: Picobirnavirus; PCV1: Porcine circovirus 1; PCV2: Porcine circovirus 2; PCVD: PCV2 disease; PERV: Porcine endogenous retroviruses; PLHV: Porcine lymphotropic herpesvirus; PMWS: Post-weaning multisystemic wasting syndrome; PoSCV: Porcine stool associated circular virus; PPEDV: porcine epidemic diarrhoea virus; ss: single stranded; TGEV: Transmissible gastroenteritis virus; TLMV: TTV-like minivirus; TTSuV-2: Torque teno sus virus-2; TTV: Torque teno virus
\end{abstract}

\section{Acknowledgements \\ The author thanks Drs. S. Norley and D. Ivanusic, Robert Koch Institute, for critical reading the manuscript and for useful comments.}

\section{Funding}

This work was supported by the Deutsche Forschungsgemeinschaft (DFG), TRR 127.

\section{Availability of data and materials \\ Not applicable.}

Authors' information

Dr. Joachim Denner, Robert Koch Institute, Nordufer 20, 13,353 Berlin, Germany.

Ethics approval and consent to participate

Not applicable.

Consent for publication

Not applicable.

\section{Competing interests}

The author declares that he has no competing interest.

\section{Publisher's Note}

Springer Nature remains neutral with regard to jurisdictional claims in published maps and institutional affiliations.

Received: 22 June 2017 Accepted: 27 August 2017

Published online: 06 September 2017

References

1. Ekser B, Tector AJ, Cooper DK. Progress toward clinical xenotransplantation. Int J Surg. 2015;23(Pt B):197-8.

2. Niemann $\mathrm{H}$, Petersen $\mathrm{B}$. The production of multi-transgenic pigs: update and perspectives for xenotransplantation. Transgenic Res. 2016;25(3):361-74.

3. Denner J. Recent progress in xenotransplantation, with emphasis on Virological safety. Ann Transplant. 2016;21:717-27.

4. Zou S, Caler L, Colombini-Hatch S, Glynn S, Srinivas P. Research on the human virome: where are we and what is next. Microbiome. 2016;4(1):32. 
5. Reichart B, Niemann H, Chavakis T, Denner J, Jaeckel E, Ludwig B, Marckmann G, Schnieke A, Schwinzer R, Seissler J, Tönjes RR, Klymiuk N, Wolf E, Bornstein SR. Xenotransplantation of porcine islet cells as a potential option for the treatment of type 1 diabetes in the future. Horm Metab Res. 2015;47(1):31-5.

6. Svensmark B, Jorsal SE, Nielsen K, Willeberg P. Epidemiological studies of piglet diarrhoea in intensively managed Danish sow herds. I. Pre-weaning diarrhoea. Acta Vet Scand. 1989;30(1):43-53.

7. Z Zhang B, Tang C, Yue H, Ren Y, Song Z. Viral metagenomics analysis demonstrates the diversity of viral flora in piglet diarrhoeic faeces in China. J Gen Virol. 2014;95(Pt 7):1603-11.

8. Shan T, Li L, Simmonds P, Wang C, Moeser A, Delwart E. The fecal virome of pigs on a high-density farm. J Virol. 2011;85(22):11697-708.

9. Lager KM, Ng TF, Bayles DO, Alt DP, Delwart EL, Cheung AK. Diversity of viruses detected by deep sequencing in pigs from a common background. J Vet Diagn Investig. 2012;24(6):1177-9.

10. Karlsson OE, Larsson J, Hayer J, Berg M, Jacobson M. The intestinal eukaryotic Virome in healthy and Diarrhoeic neonatal piglets. PLoS One. 2016;11(3):e0151481.

11. Sachsenröder J, Twardziok S, Hammerl JA, Janczyk P, Wrede P, Hertwig S, Johne R. Simultaneous identification of DNA and RNA viruses present in pig faeces using process-controlled deep sequencing. PLoS One. 2012;7(4):e34631.

12. Sachsenröder J, Twardziok SO, Scheuch M, Johne R. The general composition of the faecal virome of pigs depends on age, but not on feeding with a probiotic bacterium. PLoS One. 2014;9(2):e88888.

13. Blomström AL, Fossum C, Wallgren P, Berg M. Viral metagenomic analysis displays the co-infection situation in healthy and PMWS affected pigs. PLoS One. 2016:11(12):e0166863.

14. Dumarest M, Muth E, Cheval J, Gratigny M, Hébert C, Gagnieur L, Eloit M. Viral diversity in swine intestinal mucus used for the manufacture of heparin as analyzed by high-throughput sequencing. Biologicals. 2015;43(1):31-6.

15. Saavedra-Montañez M, Castillo-Juárez H, Sánchez-Betancourt I, RiveraBenitez JF, Ramírez-Mendoza H. Serological study of influenza viruses in veterinarians working with swine in Mexico. Arch Virol. 2017;162(6):1633-40.

16. Carocci M, Bakkali-Kassimi L. The encephalomyocarditis virus. Virulence. 2012:3(4):351-67.

17. Hause BM, Padmanabhan A, Pedersen K, Gidlewski T. Feral swine virome is dominated by single-stranded DNA viruses and contains a novel Orthopneumovirus which circulates both in feral and domestic swine. J Gen Virol. 2016;97(9):2090-5.

18. Clavijo A, Nikooienejad A, Esfahani MS, Metz RP, Schwartz S, AtashpazGargari E, Deliberto TJ, Lutman MW, Pedersen K, Bazan LR, Koster LG, Jenkins-Moore M, Swenson SL, Zhang M, Beckham T, Johnson CD Bounpheng M. Identification and analysis of the first 2009 pandemic H1N1 influenza virus from U.S. feral swine. Zoonoses Public Health. 2013;60(5):327-35

19. Corn JL, Cumbee JC, Barfoot R, Erickson GA. Pathogen exposure in feral swine populations geographically associated with high densities of transitional swine premises and commercial swine production. J Wildl Dis. 2009;45(3):713-21.

20. Feng Z, Baroch JA, Long LP, Xu Y, Cunningham FL, Pedersen $K$, Lutman MW, Schmit BS, Bowman AS, Deliberto TJ, Wan XF, Influenza A. Subtype H3 viruses in feral swine, United States, 2011-2012. Emerg Infect Dis. 2014;20(5):843-6.

21. Nelson MI, Vincent AL. Reverse zoonosis of influenza to swine: new perspectives on the human-animal interface. Trends Microbiol. 2015;23(3):142-53.

22. Broecker F, Klumpp J, Moelling K. Long-term microbiota and virome in a Zürich patient after fecal transplantation against Clostridium Difficile infection. Ann N Y Acad Sci. 2016;1372(1):29-41.

23. Minot S, Bryson A, Chehoud C, GD W, Lewis JD, Bushman FD. Rapid evolution of the human gut virome. Proc Natl Acad Sci U S A. 2013:110(30):12450-5.

24. Moustafa A, Xie C, Kirkness E, Biggs W, Wong E, Turpaz Y, Bloom K, Delwart E, Nelson KE, Venter JC, Telenti A. The blood DNA virome in 8,000 humans. PLoS Pathog. 2017;13(3):e1006292.

25. Gevers D, Knight R, Petrosino JF, Huang K, McGuire AL, Birren BW Nelson KE, White O, Methé BA, Huttenhower C. The human microbiome project: a community resource for the healthy human microbiome. PLoS Biol. 2012;10(8):e1001377.
26. Ursell LK, Clemente JC, Rideout JR, Gevers D, Caporaso JG, Knight R. The interpersonal and intrapersonal diversity of human-associated microbiota in key body sites. J Allergy Clin Immunol. 2012;129(5):1204-8.

27. Monaco CL, Gootenberg DB, Zhao G, Handley SA, Ghebremichael MS, Lim ES, Lankowski A, Baldridge MT, Wilen CB, Flagg M, Norman JM, Keller BC, Luévano JM, Wang D, Boum Y, Martin JN, Hunt PW, Bangsberg DR, Siedner MJ, Kwon DS, Virgin HW. Altered Virome and bacterial microbiome in human immunodeficiency virus-associated acquired immunodeficiency syndrome. Cell Host Microbe. 2016;19(3):311-22.

28. Denner J, Mueller NJ. Preventing transfer of infectious agents. Int J Surg. 2015;23(Pt B):306-11.

29. Pavio N, Meng XJ, Doceul V. Zoonotic origin of hepatitis E. Curr Opin Virol. 2015:10:34-41.

30. Denner J. Xenotransplantation and hepatitis E virus. Xenotransplantation. 2015;22(3):167-73.

31. Denner J. Xenotransplantation and porcine cytomegalovirus. Xenotransplantation. 2015;22(5):329-35.

32. Doucette K, Dor FJ, Wilkinson RA, Martin SI, Huang CA, Cooper DK, Sachs DH, Fishman JA. Gene expression of porcine lymphotrophic herpesvirus-1 in miniature swine with posttransplant lymphoproliferative disorder. Transplantation. 2007:83(1):87-90.

33. Chmielewicz B, Goltz M, Franz T, Bauer C, Brema S, Ellerbrok H, Beckmann S, Rziha HJ, Lahrmann KH, Romero C, Ehlers B. A novel porcine gammaherpesvirus. Virology. 2003;308(2):317-29.

34. Tucker AW, McNeilly F, Meehan B, Galbraith D, McArdle PD, Allan G, Patience C. Methods for the exclusion of circoviruses and gammaherpesviruses from pigs. Xenotransplantation. 2003;10(4):343-8.

35. Chmielewicz B, Goltz M, Franz T, Bauer C, Brema S, Ellerbrok H, Beckmann S, Rziha HJ, Lahrmann $\mathrm{KH}$, Romero C, Ehlers B. Approaching virus safety in xenotransplantation: a search for unrecognized herpesviruses in pigs. Xenotransplantation. 2003;10(4):349-56.

36. McMahon KJ, Minihan D, Campion EM, Loughran ST, Allan G, McNeilly F, Walls D. Infection of pigs in Ireland with lymphotropic gammaherpesviruses and relationship to postweaning multisystemic wasting syndrome. Vet Microbiol. 2006;116(1-3):60-8.

37. Ulrich S, Goltz M, Ehlers B. Characterization of the DNA polymerase loci of the novel porcine lymphotropic herpesviruses 1 and 2 in domestic and feral pigs. J Gen Virol. 1999;80(12):3199-205.

38. Mueller NJ, Kuwaki K, Knosalla C, Dor FJ, Gollackner B, Wilkinson RA, Arn S, Sachs DH, Cooper DK, Fishman JA. Early weaning of piglets fails to exclude porcine lymphotropic herpesvirus. Xenotransplantation. 2005;12(1):59-62.

39. Denner J, Mankertz A. Porcine Circoviruses and xenotransplantation. Viruses. 2017;9(4)

40. Quintana J, Segalés J, Calsamiglia M, Domingo M. Detection of porcine circovirus type 1 in commercial pig vaccines using polymerase chain reaction. Vet J. 2006;171(3):570-3.

41. Ruiz-Palacios GM, Pérez-Schael I, Velázquez FR, Abate $H$, Breuer $T$, Clemens SC, Cheuvart B, Espinoza F, Gillard P, Innis BL, Cervantes Y, Linhares AC, López P, Macías-Parra M, Ortega-Barría E, Richardson V, Rivera-Medina DM, Rivera L, Salinas B, Pavía-Ruz N, Salmerón J, Rüttimann R, Tinoco JC, Rubio P, Nuñez E, Guerrero ML, Yarzábal JP, Damaso S, Tornieporth N, Sáez-Llorens X, Vergara RF, Vesikari T, Bouckenooghe A, Clemens R, De Vos B, O'Ryan M. Human rotavirus vaccine study group. Safety and efficacy of an attenuated vaccine against severe rotavirus gastroenteritis. N Engl J Med. 2006;354(1):11-22.

42. Hattermann K, Roedner C, Schmitt C, Finsterbusch T, Steinfeldt T, Mankertz A. Infection studies on human cell lines with porcine circovirus type 1 and porcine circovirus type 2. Xenotransplantation. 2004;11(3):284-94.

43. Dubin G, Toussaint JF, Cassart JP, Howe B, Boyce D, Friedland L, Abu-Elyazeed R, Poncelet S, Han HH, Debrus S. Investigation of a regulatory agency enquiry into potential porcine circovirus type 1 contamination of the human rotavirus vaccine, Rotarix: approach and outcome. Hum Vaccin Immunother. 2013;9(11):2398-408

44. Li L, Deng X, Mee ET, Collot-Teixeira S, Anderson R, Schepelmann S, Minor PD, Delwart E. Comparing viral metagenomics methods using a highly multiplexed human viral pathogens reagent. J Virol Methods. 2015;213:139-46.

45. Briese T, Kapoor A, Mishra N, Jain K, Kumar A, Jabado OJ, Lipkin WI. Virome capture sequencing enables sensitive viral diagnosis and comprehensive Virome analysis. MBio. 2015;6(5):e01491-15.

46. Xu GJ, Kula T, Xu Q, Li MZ, Vernon SD, Ndung'u T, Ruxrungtham K, Sanchez J, Brander C, Chung RT, O'Connor KC, Walker B, Larman HB, Elledge SJ. Viral 
immunology. Comprehensive serological profiling of human populations using a synthetic human virome. Science. 2015;348(6239):aaa0698.

47. Kirkland PD, Daniels PW. Nor MN, love RJ, Philbey AW, Ross AD. Menangle and Nipah virus infections of pigs. Vet Clin North Am Food Anim Pract. 2002;18(3):557-71.

48. Chua KB. Nipah virus outbreak in Malaysia. J Clin Virol. 2003;26(3):265-75.

49. Frölich K, Thiede S, Kozikowski T, Jakob WA. Review of mutual transmission of important infectious diseases between livestock and wildlife in Europe. Ann N Y Acad Sci. 2002;969:4-13.

50. Barr JA, Smith C, Marsh GA, Field H, Wang LF. Evidence of bat origin for Menangle virus, a zoonotic paramyxovirus first isolated from diseased pigs. J Gen Virol. 2012:93(Pt 12):2590-4.

51. Merriman GM. Rabies in Tennessee swine. J Am Vet Med Assoc. 1966;148(7):809-11.

52. Tesh RB, Peralta PH, Johnson KM. Ecologic studies of vesicular stomatitis virus. I. Prevalence of infection among animals and humans living in an area of endemic VSV activity. Am J Epidemiol. 1969;90(3):255-61.

53. Morita K, Nabeshima T, Buerano CC. Japanese encephalitis. Rev Sci Tech. 2015;34(2):441-52

54. Elvinger F, Liggett AD, Tang KN, Harrison LR, Cole JR Jr, Baldwin CA, Nessmith WB Eastern equine encephalomyelitis virus infection in swine. J Am Vet Med Assoc. 1994;205(7):1014-1016.

55. Elvinger $F$, Baldwin CA, Liggett AD, Tang KN, Dove CR. Protection of pigs by vaccination of pregnant sows against eastern equine encephalomyelitis virus. Vet Microbiol. 1996;51(3-4):229-39.

56. Barrette RW, Metwally SA, Rowland JM, Xu L, Zaki SR, Nichol ST, Rollin PE, Towner JS, Shieh WJ, Batten B, Sealy TK, Carrillo C, Moran KE, Bracht AJ, Mayr GA, Sirios-Cruz M, Catbagan DP, Lautner EA, Ksiazek TG, White WR, McIntosh MT. Discovery of swine as a host for the Reston ebolavirus. Science. 2009;325(5937):204-6.

57. Denner J. Endogenous retroviruses. In: Kurth R., Bannert N. (eds.), Retroviruses: Molecular Biology, Genomics and Pathogenesis, Hethersett Caister Academic Press; 2010. p. 35-69.

58. Patience C, Switzer WM, Takeuchi Y, Griffiths DJ, Goward ME, Heneine W, Stoye JP, Weiss RA. Multiple groups of novel retroviral genomes in pigs and related species. J Virol. 2001;75(6):2771-5.

59. Ericsson T, Oldmixon B, Blomberg J, Rosa M, Patience C, Andersson G. Identification of novel porcine endogenous betaretrovirus sequences in miniature swine. J Virol. 2001;75(6):2765-70.

60. Groenen MA, Archibald AL, Uenishi H, Tuggle CK, Takeuchi Y, Rothschild MF, Rogel-Gaillard C, Park C, Milan D, Megens HJ, Li S, Larkin DM, Kim H, Frantz LA, Caccamo M, Ahn H, Aken BL, Anselmo A, Anthon C, Auvil L, Badaoui B, Beattie CW, Bendixen C, Berman D, Blecha F, Blomberg J, Bolund L, Bosse M, Botti S, Bujie Z, Bystrom M, Capitanu B, Carvalho-Silva D, Chardon P, Chen C, Cheng R, Choi SH, Chow W, Clark RC, Clee C, Crooijmans RP, Dawson HD, Dehais P, De Sapio F, Dibbits B, Drou N, Du ZQ, Eversole K, Fadista J, Fairley S, Faraut T, Faulkner GJ, Fowler KE, Fredholm M, Fritz E, Gilbert JG, Giuffra E, Gorodkin J, Griffin DK, Harrow JL, Hayward A, Howe K, Hu ZL, Humphray SJ, Hunt T, Hornshøj H, Jeon JT, Jern P, Jones M, Jurka J, Kanamori H, Kapetanovic R, Kim J, Kim JH, Kim KW, Kim TH, Larson G, Lee K, Lee KT, Leggett R, Lewin HA, Li Y, Liu W, Loveland JE, Lu Y, Lunney JK, Ma J, Madsen O, Mann K, Matthews L, McLaren S, Morozumi T, Murtaugh MP, Narayan J, Nguyen DT, Ni P, Oh SJ, Onteru S, Panitz F, Park EW, Park HS, Pascal G, Paudel Y, Perez-Enciso M, Ramirez-Gonzalez R, Reecy JM, Rodriguez-Zas S, Rohrer GA, Rund L, Sang Y, Schachtschneider K, Schraiber JG, Schwartz J, Scobie L, Scott C, Searle S, Servin B, Southey BR, Sperber G, Stadler P, Sweedler JV, Tafer H, Thomsen B, Wali R, Wang J, Wang J, White S, Xu X, Yerle M, Zhang G, Zhang J, Zhang J, Zhao S, Rogers J, Churcher C, Schook LB. Analyses of pig genomes provide insight into porcine demography and evolution. Nature. 2012;491(7424):393-8.

61. Patience C, Takeuchi Y, Weiss RA. Infection of human cells by an endogenous retrovirus of pigs. Nat Med. 1997;3(3):282-6.

62. Scobie $L$, Takeuchi $Y$. Porcine endogenous retrovirus and other viruses in xenotransplantation. Curr Opin Organ Transplant. 2009;14(2):175-9.

63. Denner J, Tönjes RR. Infection barriers to successful xenotransplantation focusing on porcine endogenous retroviruses. Clin Microbiol Rev. 2012;25(2):318-43.

64. Denner J. Recombinant porcine endogenous retroviruses (PERV-A/C): a new risk for xenotransplantation? Arch Virol. 2008;153(8):1421-6.

65. Garkavenko O, Croxson MC, Irgang M, Karlas A, Denner J, Elliott RB. Monitoring for presence of potentially xenotic viruses in recipients of pig islet xenotransplantation. J Clin Microbiol. 2004:42(11):5353-6.
66. Wynyard S, Nathu D, Garkavenko O, Denner J, Elliott R. Microbiological safety of the first clinical pig islet xenotransplantation trial in New Zealand. Xenotransplantation. 2014;21(4):309-23.

67. Morozov VA, Wynyard S, Matsumoto S, Abalovich A, Denner J, Elliott R. No PERV transmission during a clinical trial of pig islet cell transplantation. Virus Res. 2017;227:34-40.

68. Yang L, Güell M, Niu D, George H, Lesha E, Grishin D, Aach J, Shrock E, Xu W, Poci J, Cortazio R, Wilkinson RA, Fishman JA, Church G. Genomewide inactivation of porcine endogenous retroviruses (PERVs). Science. 2015;350(6264):1101-4.

69. Niu D, Wei HJ, Lin L, George $H$, Wang $T$, Lee $H$, Zhao HY, Wang $Y$, Kan $Y$, Shrock E, Lesha E, Wang G, Luo Y, Qing Y, Jiao D, Zhao H, Zhou X, Wang S, Wei $H$, Güell M, Church GM, Yang L. Inactivation of porcine endogenous retrovirus in pigs using CRISPR-Cas9. Science. 2017. doi:10.1126/science. aan4187.

\section{Submit your next manuscript to BioMed Central and we will help you at every step:}

- We accept pre-submission inquiries

- Our selector tool helps you to find the most relevant journal

- We provide round the clock customer support

- Convenient online submission

- Thorough peer review

- Inclusion in PubMed and all major indexing services

- Maximum visibility for your research

Submit your manuscript at www.biomedcentral.com/submit
C Biomed Central 